\title{
Tools to improve the production of emergency plans for floods - are they being used by the people that need them?
}

D Lumbroso ${ }^{1,2}$ and F Vinet ${ }^{3}$

\author{
${ }^{1}$ Laboratoire Central des Ponts et Chaussées, BP 4129, 44341 Bouguenais, France \\ ${ }^{2} \mathrm{HR}$ Wallingford, Howbery Park, Wallingford, Oxfordshire OX10 8BA, UK \\ ${ }^{3}$ Gestion des Sociétés, des Territoires et des Risques (GESTER), University of Montpellier III, France
}

Published in the Journal of Contingencies and Crisis Management, Volume 20, Issue 3, September 2012

\section{Abstract}

Major floods in Europe over the past decade have illustrated the impact of these events not only on the economy, but also on the health and well-being, as well as the safety of communities. In the past five years emergency plans, some of which focus specifically on flooding, have started to be developed in both England and Wales, and France. At present, tools, such as checklists, guidance and specialised software appear to be used rarely to improve the effectiveness of these plans. Research was undertaken with flood managers in the two countries who are responsible for providing technical input to plans. The objective was to establish why tools, methods or guidance that can usefully contribute to improving emergency plans for floods are often not being used. The research showed that many flood managers are often not aware of the tools that are available to assist them in formulating emergency plans for floods. It was concluded that there is a need for guidance on: what tools are available; what data they require; and how the tools can be implemented to provide information that can be used to improve emergency planning for floods.

\section{Introduction}

Major floods in Europe over the past decade have illustrated the potential impact of these events not only on the economy, but also on the health and well-being, as well as the safety of communities. During the last 20 years flood risk management policies have evolved significantly in various European countries (Tapsell \& Ball, 2007). It is now widely acknowledged that flood risk cannot be completely eliminated through structural measures such as flood embankments. The paradigm of attempting to reduce the flood risk as much as possible purely through structural measures has progressively been overtaken by a more holistic approach to flood risk management (Lagadec, 2002). The management of the residual risks (e.g. damage to properties, casualties) has become a priority for natural hazards such as floods. This shift in the paradigm forms the background to the Flood Risk Management Plans (FRMPs) required as part of Directive 2007/60/EC on the assessment and management of flood risks known as the Floods Directive (EC, 2007). These FRMPs include event management plans and are at the core of many proposed flood mitigation strategies. Dealing with the impacts of flood events through emergency planning and response is has become a core activity of flood risk management organizations (Defra/Environment Agency, 2008). 
Research has shown that improving an emergency response to a flood event reduces vulnerability (Defra/Environment Agency, 2008).

Recent decades have seen significant increases in the number, scope and complexity of incidents and disasters. The process of constructing a written emergency plan is of great benefit to organisations that have to respond to an emergency (Fischer III, 1996). It is now generally agreed that for places that are significantly at risk of hazards authorities should be required to produce emergency plans (Alexander, 2005). In England and France there has certainly been a culture of ongoing improvement in flood risk management and disaster preparation over the past five decades. Disaster preparation is much less costly than the implementation of structural flood mitigation measures that in many cases often cost hundreds or even billions of euro (Defra/Environment Agency, 2008; Pitt, 2008). However, the production of emergency plans in Europe specifically focused on floods is a relatively recent phenomenon. In England and Wales an Act of Parliament passed in 2004 acted as a catalyst to the formulation of emergency plans for flooding. In France an Act passed in 2005 paved the way for the production of local level emergency plans. In both countries emergency planning for floods is initially the responsibility of local government. Although regional and national flood emergencies cannot be managed exclusively at a local government level the essential remedy to an emergency situation is almost inevitably applied at a local scale (Drabek and Hoetmer, 1991).

This paper focuses on emergency management plans for floods and the tools (e.g. checklists, guidelines, methods and software) that are available to flood risk managers to assist them to produce information that can be used to inform and improve the plans. The paper has been divided into five parts. The first part provides background to flooding in England and Wales, and France, and to the approaches to emergency planning for floods. The second part provides a brief summary of the types of tools currently available to flood risk managers that can contribute to informing flood emergency plans. The third part details research that was undertaken with flood risk managers in England and Wales, and France, responsible for the technical input to these plans, to assess what tools are currently being used by them. The objective was to establish why tools, methods or guidance that could usefully contribute to improving emergency plans for floods are some times not being used. The fourth part provides a discussion and the fifth part of the paper provides conclusions.

\section{Background to emergency planning and flooding in the England and Wales and France}

In both countries there are several tiers of emergency planning ranging from national, regional to local plans. There are generic plans that focus on strategic planning covering issues such as organisation and responsibility, communication and evacuation. These plans cover other risks besides flooding. In England and Wales there are underlying plans that focus on flooding known as Multi-Agency Flood Plans (MAFPs). At a communal level in France there is the Plan Communal de Sauvegarde (PCS) ("local protection plans"). The PCSs were created to help municipalities take charge of the management of emergency planning, although PCSs focus on a range of different hazards in many areas flooding is the major threat.

\subsection{England and Wales}

In England and Wales more than 5.3 million people live and work in 2.4 million properties that are at risk of flooding from rivers or the sea. A further 2.9 million properties are susceptible to surface water flooding alone (Environment Agency, 2009a, 2009b). In June and July 2007 over 55,000 homes and 6,000 businesses 
were flooded as the result of widespread flooding and the related insurance claims were of the order of $£ 3$ billion (ABI, 2007). The floods had a significant impact on critical infrastructure over 100 sewage treatment works in the Midlands were affected. In Gloucestershire, the inundation of a water treatment plant left over 300,000 people relying on bottled water for several weeks and power supplies for over 40,000 homes were interrupted while temporary flood defences were installed at an electricity sub-station. Near Rotherham, the threat of failure of the Ulley Dam following the June 2007 rainfall was a primary factor in the evacuation of around 1,000 people (Marsh and Hannaford, 2007). The summer 2007 flooding caused damages of about $£ 674$ million to important national infrastructure and the operation of essential services. Total damage costs were greatest, in order of magnitude, for: water supplies and treatment; roads; electricity supply; agriculture and schools. National food supplies were not put at risk, although the floods made things worse in a year of general food shortages and high prices (Environment Agency, 2010). Table 1 provides details of the recent major floods in England and Wales.

Table 1: Recent major floods in England and Wales

\begin{tabular}{|c|c|c|}
\hline Date & Location & Consequences \\
\hline 2009 & $\begin{array}{l}\text { Severe flooding experienced over north-west } \\
\text { England and south-west Scotland during the } \\
\text { period } 18 \text { to } 24 \text { November }\end{array}$ & $\begin{array}{l}500 \text { homes and businesses flooded, eight } \\
\text { bridges destroyed, damage estimated at } £ 100 \\
\text { million }\end{array}$ \\
\hline 2007 & $\begin{array}{l}\text { Widespread and severe flooding afflecting } \\
\text { many rivers in June and July } 2007 \text { including } \\
\text { the lower Severn basin, headwater tributaries } \\
\text { of the Thames, as well as Yorkshire and } \\
\text { Humberside }\end{array}$ & $\begin{array}{l}14 \text { deaths, } 55,000 \text { homes and } 6,000 \text { businesses } \\
\text { inundated. Over } £ 3 \text { billion of damage }\end{array}$ \\
\hline 2005 & $\begin{array}{l}\text { The town of Carlisle, in the north-west of } \\
\text { England, suffered severe flooding }\end{array}$ & $\begin{array}{l}\text { The consequences included: three deaths; } \\
1,925 \text { homes and business flooded; } 3,000 \\
\text { people being made homeless for up to } 12 \\
\text { months, } 40,000 \text { properties without power }\end{array}$ \\
\hline 2004 & Flash flooding in Boscastle in Cornwall & $\begin{array}{l}58 \text { properties flooded and four destroyed. } \\
\text { Damage to buildings and services estimated at } \\
£ 2 \text { million }\end{array}$ \\
\hline 2000 & $\begin{array}{l}\text { Widespread flooding in November } 2000 \\
\text { throughout England and Wales }\end{array}$ & $\begin{array}{l}8,000 \text { properties were flooded with the total } \\
\text { damage estimated to be approximately } £ 500 \\
\text { million }\end{array}$ \\
\hline 1998 & Extensive areas of the Midlands flooded & Flood damage estimated at $£ 1.5$ billion \\
\hline
\end{tabular}

Sources: Dartmouth Flood Observatory, 2010; Marsh \& Hannaford, 2007; Rhodda, 2010

Emergency planning in the UK is governed by the Civil Contingencies Act 2004. In England and Wales the primary responsibility for planning for and responding to any major emergency rests with local organisations, acting individually and collectively through Local Resilience Forums (LRFs) (Defra/Environment Agency, 2010). There are currently 47 LRFs covering England and Wales that are based on the administrative boundaries of the police. The LRF is a multi-agency partnership made up of representatives from local public services, including the fire and ambulance services, local authorities, the health service and flood risk managers from the Environment Agency. In the context of the emergency planning framework Multi-Agency Flood Plans (MAFP) provide specific information on flooding. MAFPs are produced by the LRF. Each LRF has to consider the flood risk across the whole area for which it is responsible. 


\subsection{France}

Flood risk is the most important natural disaster in France, in terms of the area at risk. More than $40 \%$ of the 36,500 French communes are affected by floods and flooding is responsible for $80 \%$ of the damage attributable to French natural disasters (Pottier et al, 2005). Approximately $20,000 \mathrm{~km}^{2}$ of land is regularly affected by floods with 4.5 million people potentially affected (Enjolras et al, 2008). Table 2 provides a brief overview of some of the most serious floods that have occurred in France in the past ten years.

Table 2: Recent major floods in France

\begin{tabular}{|c|c|c|}
\hline Date & Location & Consequences \\
\hline 15 June 2010 & Var Département in southern France & 28 people killed as the result of flash floods \\
\hline $\begin{array}{l}28 \text { February } \\
2010\end{array}$ & $\begin{array}{l}\text { West Atlantic Coast, Vendée and } \\
\text { Charente regions of western France }\end{array}$ & $\begin{array}{l}47 \text { people killed as the result of coastal flooding } \\
\text { owing to dike failures }\end{array}$ \\
\hline $\begin{array}{l}15 \text { November } \\
2005\end{array}$ & Southern France, Perpignan area & Two people killed as the result of flash floods \\
\hline $\begin{array}{l}6 \text { to } 9 \\
\text { September } \\
2005\end{array}$ & $\begin{array}{l}\text { Gard and Herault areas and Nimes. } \\
\text { Lunel and Montpellier }\end{array}$ & Two people killed as the result of flooding \\
\hline $\begin{array}{l}1 \text { to } 3 \\
\text { December } \\
2003\end{array}$ & $\begin{array}{l}\text { Southern France - Rhone valley - } \\
\text { Marseilles and Lyon areas. Bouches- } \\
\text { du-Rhone region. Vaucluse, Ardeche, } \\
\text { Charlieu, Avignon, Orange. Herault, } \\
\text { Gard, Arles, Ardeche. }\end{array}$ & $\begin{array}{l}\text { Nine people killed as the result of fluvial floods, } \\
\text { flash floods and dike failure. Damage estimated } \\
\text { at } € 1.5 \text { billion }\end{array}$ \\
\hline $\begin{array}{l}8 \text { September } \\
2002\end{array}$ & $\begin{array}{l}\text { Gard, Herault and Vaucluse } \\
\text { departments. Nimes and Avignon } \\
\text { areas. Aramon, Sommieres, Russon. }\end{array}$ & $\begin{array}{l}23 \text { deaths as the result of flash floods. Damage } \\
\text { estimated at } € 1.19 \text { billion }\end{array}$ \\
\hline
\end{tabular}

Sources: Dartmouth Flood Observatory, 2010; Kolen et al, 2010; EM-DAT-CRED, 2011

Risk Prevention Plans (RPPs or Plan de Prévention du Risque (PPR)) are the documents in which floodplains are delineated in France. RPPs are set up by central government, through the responsibility of its local representative, the préfet. RPPs identify the limits of floodplains and map different flood hazard zones, each of which is associated to specific regulatory restrictions. In France an Act passed in 2005 paved the way for the production of local level emergency plans. In terms of emergency planning at a communal level there are now what are known as the Plan Communal de Sauvegarde (PCS), i.e. "the local protection plan". The PCSs were created to help municipalities taking charge of the management of emergency planning at a local level (Direction de la Defence et de la Securitie Civiles, 2004).

The PCS is the first plan that is put into action when an emergency occurs. The PCS is activated by the mayor of each commune. French citizens expect the mayor and their representative at a commune level to be at the forefront of emergency management (Lagadec \& Guilhou, 2002). At a départemental level there are plans that complement the PCS, which set out rescue and evacuation strategies. These plans are activated when an emergency becomes too difficult or large for local authorities to handle. Approximately 10,000 French communes are required by law to have PCSs, to date only approximately 5,000 have been completed. In France the production of the PCSs is the responsibility of the elected mayor of each commune. Unlike England and Wales there is no method of stakeholder liaison to allow the incorporation of the expertise and local knowledge of flood risk managers directly into the plans. 


\subsection{Comparison between flood risk management policy and practice in England and Wales and France}

Flood risk management policy in the two countries can be compared using a safety chain concept, developed by the Federal Emergency Management Agency in the USA, to address safety and security concerns. Ten Brink et al (2008) defined five links in the chain and compared the relative effort put into each link in England and Wales and France. Table 3 illustrates that the relative effort put into each link in each of the two countries is almost the same and in that respect it could be considered that flood risk management policy is similar in both countries. However, there are considerable differences in the ways in which the policies are implemented, that are discussed below, and these inevitably have an effect on the emergency planning for floods and the tools that are used by flood managers to inform the plans.

Table 3: Definition of links in the safety chain and the relative effort put into each in England and Wales and France

\begin{tabular}{|c|c|c|c|c|}
\hline & \multirow[b]{2}{*}{ Link } & \multirow[b]{2}{*}{ Definition } & \multicolumn{2}{|c|}{ Relative effort put into each link } \\
\hline & & & $\begin{array}{l}\text { England and } \\
\text { Wales }\end{array}$ & France \\
\hline \multirow[t]{2}{*}{$\begin{array}{l}\text { Risk } \\
\text { management }\end{array}$} & Pro-action & $\begin{array}{l}\text { Eliminating structural causes of } \\
\text { floods to prevent them from } \\
\text { happening (e.g. avoidance of } \\
\text { construction in the floodplain) }\end{array}$ & Strong emphasis & $\begin{array}{l}\text { Average to } \\
\text { strong emphasis }\end{array}$ \\
\hline & Prevention & $\begin{array}{l}\text { Taking measures beforehand that } \\
\text { aim to prevent floods and limit } \\
\text { their consequences (e.g. the } \\
\text { construction of structural flood } \\
\text { defences) }\end{array}$ & $\begin{array}{l}\text { Average } \\
\text { emphasis }\end{array}$ & $\begin{array}{l}\text { Average } \\
\text { emphasis }\end{array}$ \\
\hline \multirow[t]{3}{*}{$\begin{array}{l}\text { Emergency } \\
\text { management }\end{array}$} & Preparation & $\begin{array}{l}\text { Taking measures to ensure there } \\
\text { is sufficient preparation to deal } \\
\text { with floods (e.g. emergency } \\
\text { planning) }\end{array}$ & $\begin{array}{l}\text { Very strong } \\
\text { emphasis }\end{array}$ & $\begin{array}{l}\text { Very strong } \\
\text { emphasis }\end{array}$ \\
\hline & Response & Dealing with floods & $\begin{array}{l}\text { Very strong } \\
\text { emphasis }\end{array}$ & $\begin{array}{l}\text { Very strong } \\
\text { emphasis }\end{array}$ \\
\hline & Recovery & $\begin{array}{l}\text { Activities that lead to a rapid } \\
\text { recovery from the flood to allow } \\
\text { the situation to return to normal }\end{array}$ & Strong emphasis & Strong emphasis \\
\hline
\end{tabular}

Source: Adapted from ten Brinke et al, 2008

In terms of the management of flood defence assets, nearly a third of the dikes in France have no known owner or are in the hands of local residents or municipalities with insufficient funds to maintain them. In many cases it is not clear who manages the thousands of kilometres of flood defences along rivers and the French coast (Le Monde, 2010). Anziani (2010) states that in France "it is imperative to change the complex and uncontrolled system of the management of flood defence dikes. Too many organisations are involved in their management. Despite increased regulatory control since December 2006 flood defence dikes are poorly maintained....it is essential that where maintenance responsibilities for levees are not defined that control is taken by a competent authority". Throughout England and Wales there is some 38,000 km of flood defences 
and 46,000 flood defence structures (NAO, 2007). Unlike in France these are managed and maintained by one organisation, the Environment Agency. In France there is no national technical guidance on flood defence maintenance (Dupay et al, 2010). The other key difference in England and Wales is that the Environment Agency has established a rigorous system for classifying, recording and monitoring the condition of flood defence assets, including a database containing comprehensive information on the state of flood defences (NAO, 2007) that allows resources to maintain and operate them to be allocated systematically rather than on an ad hoc basis as appears to be the case in France.

In England and Wales the responsibility for fluvial and coastal flood forecasting and warning is also held by the Environment Agency. In France a national flood forecasting service, "Service Central d'Hydrométéorologie et d'Appui à la Prévision des Inondations" (SCHAPI) with 22 regional offices was sent up in 2003 (MEEDDM, 2004). Unlike the Environment Agency SCHAPI only forecasts fluvial flood flows and levels and it does not disseminate warnings to a wide variety of stakeholders in a number of different forms as is the case in England and Wales. The assessment of the probability of floods and the risk they pose is the responsibility of the Direction Régionale de l'Environnement, de l'Aménagement et du Logement (DREAL) in France. This is a separate organisation from SCHAPI and one that is not responsible for the management of flood defence assets. The fragmented manner in which flood risk management from a variety of sources (e.g. rivers, coasts, pluvial) is organised in France is in stark contrast to the more unified and holistic approach of the Environment Agency. The same is true of emergency planning for floods. In France there are no stakeholder forums that allow mayors to involve SCHAPI and DREAL in the drafting of the parts of the PCSs relating to floods that usually form the majority of the plans. In England and Wales the Environment Agency has a direct link and input into the production of the MAFPs via the LRFs. These differences in cultures of flood risk management between the two countries are reflected to a certain extent in the tools that are used by flood risk managers. This is further discussed in the fourth part of the paper.

\subsection{Issues identified with flood emergency plans in England and Wales and France}

As part of research recently undertaken to assess flood emergency plans in England and Wales and France 22 metrics have been developed (Lumbroso et al, 2011). These metrics cover a range of issues from the aims and objectives of the plan to training and exercises. The developed metrics and survey of emergency planners provided a basis to compare flood emergency plans in the two countries. An assessment of plans found that areas such as the roles, responsibilities and communication is essential for a plan to be effective and that these aspects tend to be well covered in the two countries looked at. However, other more technical aspects such as accessibility of roads during floods, evacuation, and the depiction of flood hazard and impacts of floods on critical infrastructure can be considerably improved (Lumbroso et al, 2010, 2011). There was often a discrepancy between the level of detail required by emergency planners and the actual level of detail that is available in the plans (Lumbroso et al, 2010, 2011). The discrepancy between emergency planners' requirements was found to greatest for matters related to the risk floods pose to people in terms of injuries and lose of life; buildings; critical infrastructure and accessibility to flooded areas (Lumbroso et al, 2010, 2011).

Recent research in the two countries has shown that many emergency planners believe that the effectiveness of a flood emergency plan can only truly be assessed accurately after the plan has been used to respond to a large flood event (Lumbroso et al, 2010, 2011). A recent evaluation of a flood emergency plan used in the county of Cumbria in northern England during severe, widespread flooding in November 2009 highlighted the usefulness of tools to assess the vulnerability of critical infrastructure such as location of 
electricity sub-stations and care homes, as well as the possible inundation of roads with a flooding history outside the formal flood warning areas. These were also seen as very useful both to strategic and tactical response by the police and other key emergency responders (Cumbria LRF, 2010).

Emergency plans both in England and Wales and in France currently make use of local knowledge from a wide range of stakeholders with regards to the impact historical floods, the vulnerability of stakeholders and the response during a flood event. Research carried out recently indicated that generally local knowledge was incorporated well into the plans as a result of stakeholder consultations and forums (Lumbroso et al, 2010b). However, in many parts of the two countries communities are heavily defended against flooding by structural mitigation measures and as a result have often not experienced flooding in living memory. Clarke (2006) and ten Brinke (2010) make the case for "worst case thinking" and its application to emergency planning for flood events. Clarke argues that emergency plans should not be biased in favour of what has already happened in the past. Clarke (2006) also highlights the often narrow understanding of complex systems and laments the hubris that allows many stakeholders to think that they can be controlled and the selective understanding of the infrastructure informs failed disaster planning. Clarke argues when policymakers plan for disasters, they too often think in terms of past experiences and probabilities ("probabilism").

Using statistics and knowledge of previous events can limit the "out of the box" thinking that is needed to explore future possibilities (ten Brinke, 2010). It is important that policy makers think about worst case disasters even though they may seem purely hypothetical events (Boin et al, 2005; Clarke, 2006) because "things that have never happened before happen all the time" (Sagan, 1993). Thinking in terms of "worst cases" and that which is possible ("possibilism") can be more enlightening in terms of emergency planning (Clarke, 2006). To have a realistic understanding of the risks for low probability events it is often important to utilise tools to assess, for example, the impact the failure of critical infrastructure, such as water, energy, waste and transport systems, can have in terms of damage caused to the environment, cost to the economy, and loss of life. Clarke (1999) pointed out for many emergency planners it can be easier to produce symbolic, "fantasy" documents than to engage in forthright admissions of real dangers and the uncertainties that they create. Perry and Lindell (2003) suggest that emergency management processes should be based on an accurate knowledge of the threats. It can be argued that if the approaches to emergency planning suggested by Clarke and Perry \& Lindell had been taken in France the number of people that died as a result of the coastal flooding caused by "la tempête" Xynthia in February 2010 could have been significantly reduced.

A survey of 172 emergency planners in the two countries (Lumbroso et al, 2010,2011) indicated that recent floods have raised the importance of the protection of the critical infrastructure (e.g. power stations, water supply networks) against the impact of floods, accessibility of flood zones, the vulnerability of buildings, as well as how loss life as the result of flood events can be reduced. However, there appeared from a review of MAFPs and PCSs undertaken little evidence that flood managers responsible for advising emergency planners on these issues were making use of the full range of tools available to them. This has in some cases resulted in flood emergency plans that are merely symbolic and that as Clarke (1999) states "are used as forms of rhetoric to convince audiences that they ought to believe what an organization says" and that have "little instrumental utility in them". The third part of this paper provides some background to the tools that are currently available to flood risk managers to assist them in assessing possible risks posed by floods and to help them ameliorate emergency plans so that they address the issue of "possibilism". The fourth part of the paper then investigates the use of tools amongst flood managers. 


\section{Background to tools}

The tools that are currently readily available to assist flood managers in providing information on the flood risk to various plans can be broadly grouped into the following groups:

- Flood hazard mapping

- Assessment of risk to people from floods

- Estimation of the evacuation times zones at risk of inundation

- Assessment of the accessibility of roads

- Impacts of the failure of critical infrastructure

These tools are briefly detailed below.

\subsection{Flood hazard mapping tools}

Flood extent, depth, and velocity maps form the basic information for emergency planners, who have to prepare emergency plans (van Alphen et al, 2009). There is a large volume of information that already exists on flood hazard modelling and mapping tools. In the past decade the use of two dimensional hydraulic tools to model inundations has become increasingly prevalent in the two countries. This has meant that it is now possible to produce flood hazard maps that show not only flood extents, but also depths, velocities or a combination of these two parameters.

In England and Wales there are three main types of flood maps that are used to inform MAFPs, these are:

- Fluvial and coastal flood map that shows the maximum undefended flood extent

n Surface water flood map that shows areas that may be susceptible to surface water flooding

- Reservoir inundation maps that shows the maximum flood extent in the case of a dam failure

The above maps only show flood extents and give no indication of maximum depths or velocities. An example of a flood map produced by the Environment Agency is shown in Figure 1.

In France, the majority of flood hazard maps used in emergency plans are taken from a Plan de Prévention du Risque (PPR). PPRs are a legal requirement documenting the risks that a particular commune is prone to. The main objective of PPRs is to assist with spatial planning decisions. As a consequence of this, the maps contained in PPRs conform to these requirements and generally only show the maximum extent of a flood for a particular return period similar to the case in England and Wales.

The reference return period for flood maps for PPRs is the 1 in 100 year return period or a historical flood outline if this is greater than the 1 in 100 year extent. Owing to the fact that the flood maps in the PPRs are produced to regulate land use planning, they often do not meet the needs of emergency planners. This is because they rarely provide an "intermediary level of the flood hazard" (e.g. the 1 in 30 or 1 in 50 year flood extent) and they often do not often show other parameters that are relevant to emergency planners such as maximum floodwater velocities and depths. 


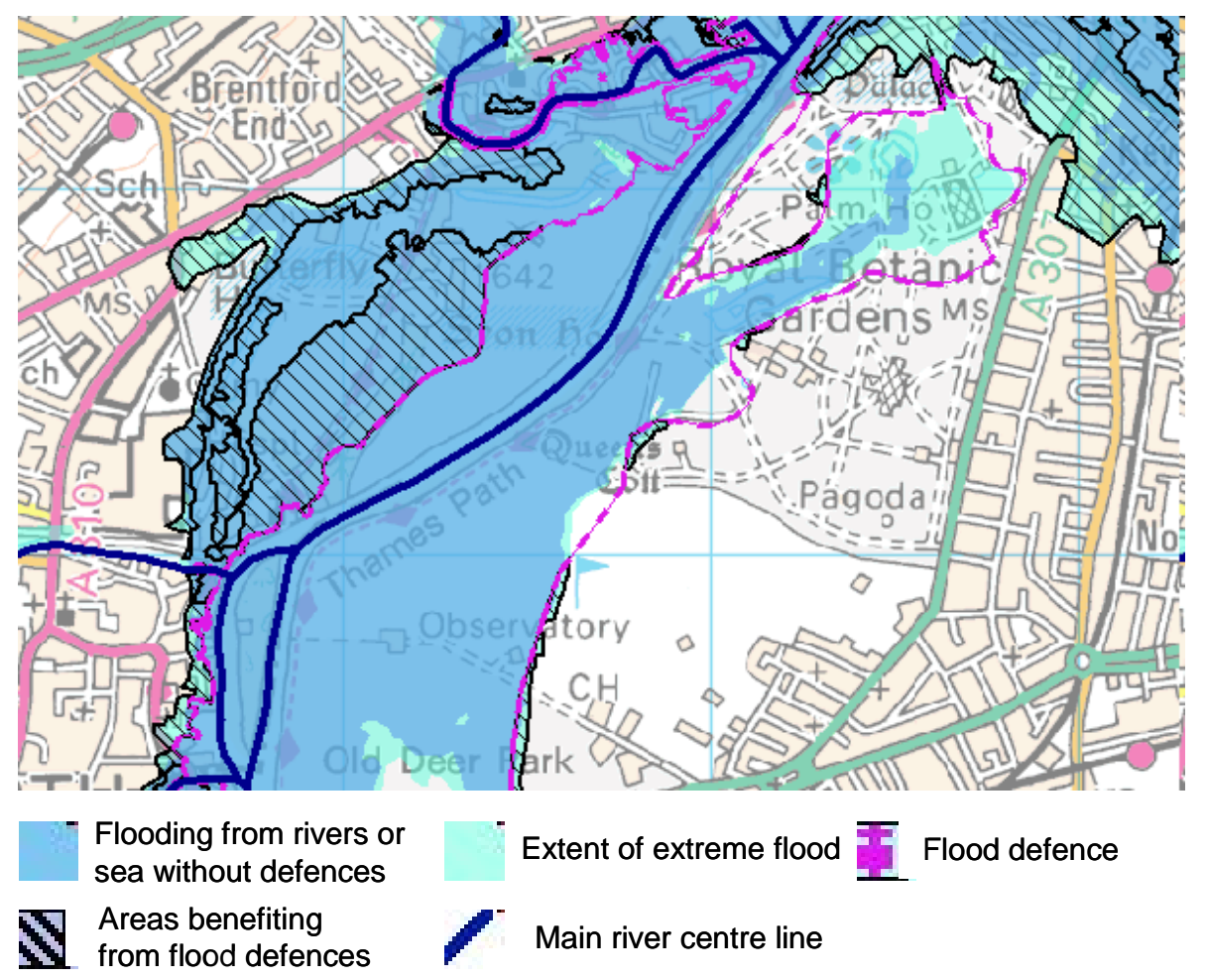

Figure 1: Example of a flood extent map of part of the River Thames

Apart from cases where important assets, such as critical infrastructure, are at risk, the maximum floodwater velocity is not calculated. In France a general assumptions is made that in the northern part of the country floodwater velocity is relatively "low" because floods are generally caused by rivers that rise relatively slowly (e.g. the Loire, the Seine). Whereas in southern France, where many areas are subject to flash floods, the flood water velocity is assumed to exceed $0.5 \mathrm{~m} / \mathrm{s}$ everywhere.

The floods maps for emergency plans can be classified into three levels of details.

1. Maps showing just the maximum flood extent

2. Maps providing maximum flood extent and water depth

3. Maps showing maximum flood extent, depths and velocity

Ideally the maps should show these parameters for a range of return periods. There are some limited examples where maps including flood depth for a range of return periods have been included in emergency plans in France. In England and Wales, and France it can be concluded that the flood maps in emergency plans are generally based on flood hazard maps produced to regulate land use planning and not directly produced to assist with emergency planning.

\subsection{Tools to assessing the flood risk to people}

Despite the impacts of floods globally it is only recently that models have become available for the estimation of loss of life caused by inundations (Jonkman, 2007). There are a variety of tools that have been produced and that are available to inform emergency plans. These models include some form of "mortality function" 
that relates loss of life to various characteristics of the flood, depending on the complexity of the model. A brief overview of the tools that are available is described below.

The US Bureau of Reclamation (Graham, 1999) and Risk to People (Defra, 2006) methods provide simple means for assessing and mapping the risk of death or serious harm to people caused by flooding based on empirical data. A typical output from these tools that can be of use to inform emergency plans is shown in Figure 2.

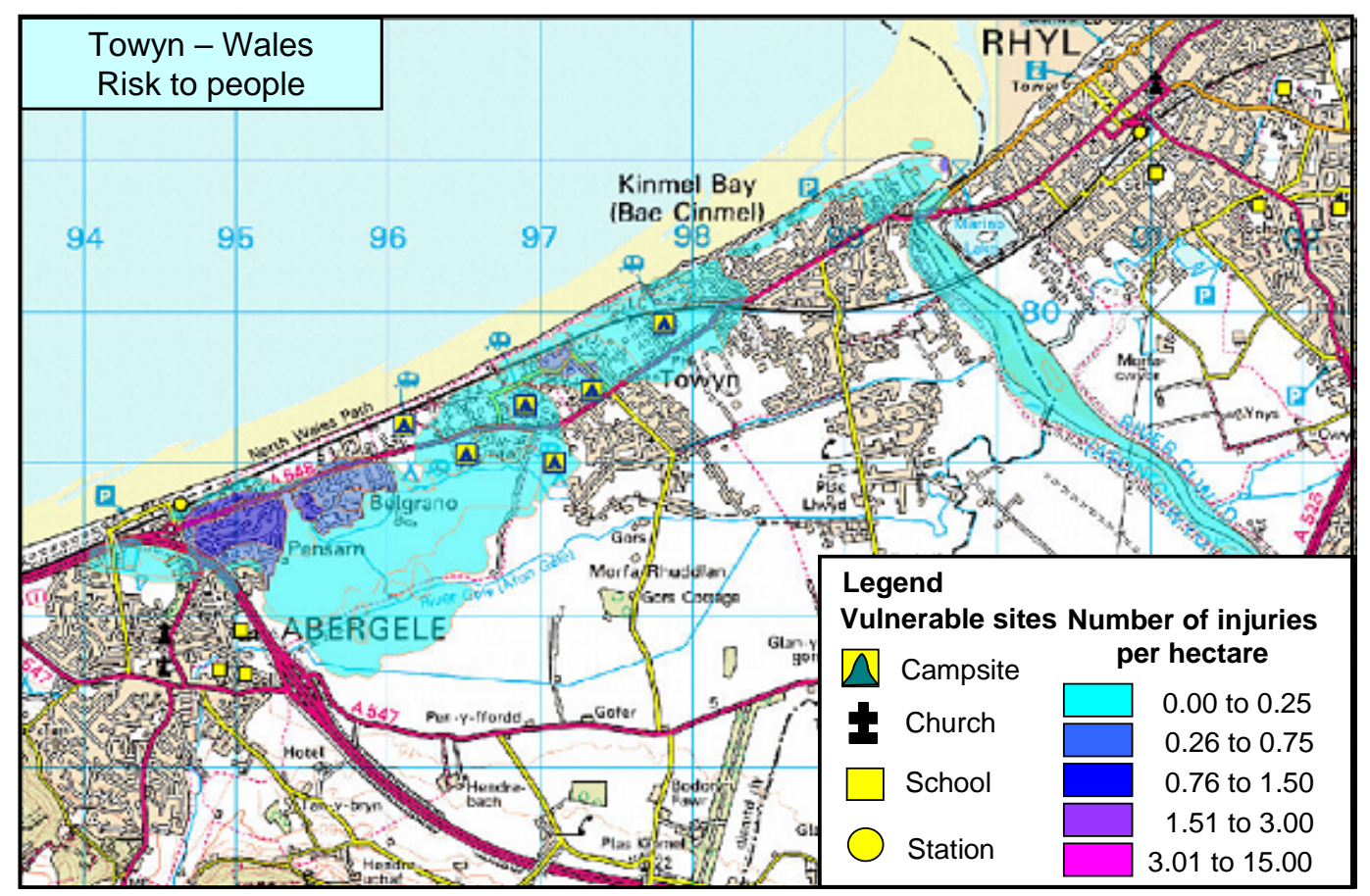

Figure 2: Example of a risk to people map of Towyn in Wales showing the potential number of injuries for a failure of the coastal flood defences

Other more complex models such as the Life Safety Model (LSM) and LifeSim models use detailed local data and capture the flood mechanisms that can cause fatalities (Johnstone et al, 2005; Aboelata \& Bowles, 2005). The LSM is the most detailed of the tools available because it simulates an individual's fate during a flood event and includes a simple traffic model, a building collapse function and also simulates the possibility of vehicles being swept off roads by the floodwave (Di Mauro and Lumbroso, 2008). The LSM can be used to develop evacuation strategies for floods. The LifeSim model distinguishes groups of people, whose circumstances are comparable. The disadvantage of such an approach is that a large number of behavioural variables have to be assigned to the people potential affected by floods, for which very limited empirical information is available (Jonkman, 2007).

\subsection{Tools to assess the evacuation times for floods}

Evacuation has the potential to save lives, but can be costly in time, money, and credibility. Different types of evacuation can be distinguished such as: preventive evacuation; vertical evacuation to safe havens or shelters; or "shelter in place". The consequences in terms of reducing the risk to life depends on the required time to evacuate, which is related to the type of evacuation, characteristics of the area and type of flooding. Tools to assess the evacuation times for floods are important for stakeholders responsible for the efficient 
and safe movement of people during an evacuation. They can identify "bottlenecks" in the areas before they are experienced during an evacuation, and they can also be used to determine the impact of road closures due to flooding, the impact of phased evacuation on traffic loading, and other possible consequences.

In England and Wales, and France tools to assess evacuation times appear to be rarely used by emergency planners. However, there are a number of tools that have been developed for specific use in flood risk management mainly in the Netherlands. There are various scales at which evacuation modelling can be carried out. Macro-scale evacuation models are useful for obtaining first order estimates of evacuation times for relatively large areas. Meso- and micro-scale models are needed for detailed evacuation planning.

In some cases, for results to be useful, there is a need for individual receptors (e.g. people, houses, vehicles) to be modelled and for additional information to be provided (e.g. loss of life and injury estimates, effects of different management plans) not just evacuation times. Micro-scale models, although more time consuming to set up than macro models, provide emergency planners and other end users with more insight into the areas at greatest risk, and also provide decision makers with other risk metrics (e.g. number of collapsed buildings, loss of life, inundation of escape routes). However, to be effective such models should be applied to the whole area at risk. Such micro-scale models can also be used to inform flood emergency planning exercises.

\subsection{Tools to assess accessibility of roads and the vulnerability of critical infrastructure and buildings}

Information on industrial accidents triggered by natural events (NaTech) and damage to critical infrastructure are important for emergency plans. There are few readily available tools that can provide information on these. In the case of floods no simplified equipment damage models are available in the literature. There is only very limited data available to analyze in detail the damage caused by floods to industrial equipment. The information about past accidents recorded in industrial accident databases is usually not sufficiently detailed, in particular with respect to the description of the structural damage of equipment caused by the floods. There have been some limited tools available to assess NaTech hazards using simple damage functions such as those developed by Bonvicini et al (2009).

In terms of accessibility of roads in the early 1990s Keller and Mitsch $(1992,1993)$ carried out research on the stability of both cars and people in flood conditions. The research considered the physics of vehicles in floodwater conditions. The analysis of vehicle stability involved calculations for three types of common cars. This work has led to a simple guidance that can be used to inform the accessibility of roads during flood events.

In France since the creation of the PCS, tools to optimize evacuation routes and to assess the access to inundated areas are being developed such as "Itineris". Itineris calculates the optimal route for rescue vehicles to access inundated areas taking into account roads cut off by floods or blocked by traffic. Prototype models have also been developed to map possible road inundations in the Gard region of the south-east of France, an area that is frequently subject to severe flash floods (Versini et al, 2010). The objective is link the inundation model with a road network model to provide emergency services with a forecast of what roads are likely to be closed a few hours before a major flash flood occurs.

A number of tools have been developed to assess the probability of buildings collapsing or being damaged during floods. For example Clausen \& Clark (1990) developed simple methods for predicting flood damage to buildings during extreme floods based on the velocity and depth of the water. Work in this area has also been carried out by Lorenzen et al (1975) and Smith (1994). 


\section{The awareness and obstacles to the use of tools amongst flood managers}

Flood risk managers in England and Wales and France who are responsible for providing information to inform the development of emergency plans for flood were engaged in the research through two main methods:

- Face-to-face discussions

- An online survey in English and French that was disseminated to flood risk managers who provide technical input and advice to emergency planners and work with them to produce flood emergency plans within the two countries. In England and Wales 53 flood risk managers who work for the Environment Agency staff answered the online survey and in France 77 flood risk managers who work for both DREAL and SCHAPI responded to it

This allowed the level of awareness that they had of the available tools to be assessed.

\subsection{The perceived use of tools to inform flood emergency plans}

As part of the online survey flood managers in the two countries were asked which tools, methods and guidelines they used or knew of that were of use in formulating emergency plans for floods. The following choices given in the survey together with the responses are given in Table 4.

In relation to the perceived level of use of tools in the two countries, Table 4 shows that generally the use of tools to inform flood emergency plans is perceived to be much higher in England and Wales than it is in France.

The perceived level of use of fluvial flood hazards to inform emergency plans was very high (>90\%) in both countries. Floodplain mapping and hydraulic modelling for rivers are both "mature sciences" in Europe with hundreds of millions of Euros worth of mapping studies and modelling exercises being undertaken in the past decade. As a consequence it is understandable that in both countries fluvial flood hazard maps are readily available and are used to inform plans. In France the level of awareness of tools to assess coastal hazards was low, around 20\% compared to $80 \%$ in England and Wales.

Historically flooding from the sea has been higher up the political agenda in England and Wales than in France. This is probably because London is located on a tidal estuary and after 307 people died in the UK as the result of coastal flooding from the North Sea in 1953 the issue of coastal flooding and defence gained new prominence with British politicians (Gilbert, 1986). This led directly to a policy in England and Wales that focused on the raising and strengthening of coastal flood defences and the eventual construction of the Thames Barrier to protect London and the Thames Estuary (Penning-Rowsell et al, 2006).

In France, the low perceived level of the use of tools to assess coastal floods may be due to the fact that, until recently, the risks posed by coastal flooding in France were perceived to be relatively low by stakeholders. Historians such as Coeur argue that in France the focus has generally been on fluvial flood because the major cities and the political centres (i.e. Paris, Lyon, the Tourain region) are adjacent or traversed by France's largest rivers and have experienced the most extreme floods (i.e. River Rhone 1856 in Lyon, River Seine flood in Paris, 1910) (Coeur, 2002; Jackson, 2010). Although there have been coastal floods in the past in France (Garnier \& Surville, 2010) owing to the centralized nature of the French 
Government system and the fact that the main centres of political influence are subject to fluvial flooding, flood prevention in France has focused mainly on major rivers rather than the coast.

Table 4 shows that the perceived level of use of tools was higher or the same in England and Wales than in France for all bar one type of tool. This may well reflect the fact that as discussed in part 2 of this paper flood risk management is more "joined-up" in England and Wales and less compartmentalized than it is in France. The disjointed organizational structure of flood risk management in France means that it is likely to more difficult to disseminate new methods and tools than it is in England and Wales. The survey results also bear out the fact that in France most flood risk managers tend to concentrate on the technical aspects of fluvial floods rather than having a more holistic approach to flood hazards and risk as is the case in England and Wales.

Table 4: Perceived level of use of tools to inform emergency plans by flood risk managers

\begin{tabular}{|l|l|l|}
\hline & \multicolumn{2}{|l|}{$\begin{array}{l}\text { Precentage of } \\
\text { responders who } \\
\text { perceive the tools as } \\
\text { being used }\end{array}$} \\
\cline { 2 - 3 } $\begin{array}{l}\text { England } \\
\text { and } \\
\text { Wales }\end{array}$ & France \\
\hline Type of tool & $98 \%$ & $98 \%$ \\
\hline Fluvial flood mapping hazard tools & $80 \%$ & $18 \%$ \\
\hline Coastal flood hazard mapping tools & $58 \%$ & $43 \%$ \\
\hline Methods to assess the flood hazard posed by dam failure & $58 \%$ & $38 \%$ \\
\hline Methods to assess other sources of flood hazard (e.g. surface water flooding) & $53 \%$ & $33 \%$ \\
\hline Tools to assess the accessibility of inundated roads and evacuation routes & $51 \%$ & $20 \%$ \\
\hline Optimisation of shelters locations with respect to the flood hazard & $49 \%$ & $23 \%$ \\
\hline Assessment of the damage to critical infrastructure by floods & $42 \%$ & $8 \%$ \\
\hline Tools to assess optimal evacuation routes and times & $40 \%$ & $30 \%$ \\
\hline Methods to assess how improvements in flood warning affect the risk to people & $36 \%$ & $18 \%$ \\
\hline Methods to asesss possible injuries and loss of life caused by floods & $18 \%$ & $13 \%$ \\
\hline Inter-dependency of critical infrastructure and the consequences of this & $13 \%$ & $10 \%$ \\
\hline Tools to assess other hazards (e.g. NaTechs) that can be triggered by floods & $2 \%$ & $5 \%$ \\
\hline Probability of building collapse triggered by floods & & \\
\hline
\end{tabular}

The most interesting part of the survey was that when asked the responders what tools they actually use very few flood managers explicitly named tools that can assess, for example, the accessibility of roads, damage to critical infrastructure, loss of life etc, even though they mentioned that they used them to inform their emergency management plans. This discrepancy between the perceived and actual use of tools by flood managers and the perceived obstacles to the use of the tools available is discussed below.

\subsection{Obstacles to the use of the available tools}

The primary objective of the survey was to assess the perceived obstacles to using tools by flood managers. Flood managers were asked if they currently used the tools and if not to classify the reason into one of the 
following: "Not relevant to emergency plans for floods"; "Unaware of the method"; "Cost"; "User friendliness issues"; "Availability of data"; "Other reasons". The results of the survey are discussed below under three main headings:

1. Tools to assess flood hazards from different sources

2. Tools to assess risk to people, evacuation routes, accessibility and flood warnings

3. Tools to assess risk to critical infrastructure, location of shelters, assessment of NaTechs and the probability of building collapse

\subsubsection{Tools to assess flood hazards from different sources}

Table 5 summarises the results of the survey for tools relating to flood hazard. The use of tools to assess fluvial floods in both countries was high. Only approximately $44 \%$ of responders in France stated that they currently use tools to assess coastal hazards, this contrasts with the $20 \%$ of responders who perceived that the output from these tools are currently used to inform emergency plans. With respect to assessing flood hazard from dams the major obstacle for these methods not being employed more frequently was "availability of data". Some $25 \%$ of responders in England and Wales and France indicated that this was an issue. Regarding assessing flood hazards from other sources (e.g. pluvial flooding) in France almost $20 \%$ of responders were unaware of methods to assess this hazard.

Table 5: Perceived obstacles to using tools to assess flood hazard from different sources

\begin{tabular}{|c|c|c|c|c|c|c|c|c|}
\hline \multirow[b]{2}{*}{ Response } & \multicolumn{2}{|c|}{$\begin{array}{l}\text { Fluvial flood } \\
\text { hazard }\end{array}$} & \multicolumn{2}{|c|}{$\begin{array}{l}\text { Coastal flood } \\
\text { hazard }\end{array}$} & \multicolumn{2}{|c|}{$\begin{array}{l}\text { Dam flood } \\
\text { hazard }\end{array}$} & \multicolumn{2}{|c|}{$\begin{array}{l}\text { Other sources of } \\
\text { flood hazard }\end{array}$} \\
\hline & $\begin{array}{l}\text { Englan } \\
\text { d and } \\
\text { Wales }\end{array}$ & France & $\begin{array}{l}\text { Englan } \\
d \text { and } \\
\text { Wales }\end{array}$ & France & $\begin{array}{l}\text { Englan } \\
d \text { and } \\
\text { Wales }\end{array}$ & France & $\begin{array}{l}\text { Englan } \\
d \text { and } \\
\text { Wales }\end{array}$ & France \\
\hline Currently used & $88.6 \%$ & $100.0 \%$ & $70.6 \%$ & $44.0 \%$ & $42.9 \%$ & $50.0 \%$ & $51.5 \%$ & $38.0 \%$ \\
\hline Not relevant to plans & $0.0 \%$ & $0.0 \%$ & $20.6 \%$ & $17.0 \%$ & $5.7 \%$ & $0.0 \%$ & $3.0 \%$ & $10.0 \%$ \\
\hline Unaware of method & $5.7 \%$ & $0.0 \%$ & $2.9 \%$ & $17.0 \%$ & $11.4 \%$ & $14.0 \%$ & $9.1 \%$ & $24.0 \%$ \\
\hline Cost & $0.0 \%$ & $0.0 \%$ & $0.0 \%$ & $0.0 \%$ & $0.0 \%$ & $5.0 \%$ & $3.0 \%$ & $0.0 \%$ \\
\hline $\begin{array}{l}\text { User friendliness } \\
\text { issues }\end{array}$ & $2.9 \%$ & $0.0 \%$ & $2.9 \%$ & $0.0 \%$ & $2.9 \%$ & $5.0 \%$ & $6.1 \%$ & $5.0 \%$ \\
\hline Availability of data & $0.0 \%$ & $0.0 \%$ & $0.0 \%$ & $6.0 \%$ & $22.9 \%$ & $23.0 \%$ & $24.2 \%$ & $19.0 \%$ \\
\hline Other reasons & $2.9 \%$ & $0.0 \%$ & $2.9 \%$ & $17.0 \%$ & $14.3 \%$ & $5.0 \%$ & $3.0 \%$ & $5.0 \%$ \\
\hline
\end{tabular}

It is noticeable that the use of tools to assess the coastal flood hazard is much higher in England and Wales than in France. This is mainly a result of the result of the differences in organisational aspects of flood risk management in the two countries discussed above. The current perceived use of tools to assess the hazard of flooding from dams was slightly higher in France and this is probably a result of the recent reinforcement of legal requirements relating to dam safety.

It is interesting to note that the level of awareness regarding surface water flooding tools was much higher in England and Wales than in France. Much of the flooding that occurred in England in 2007 was the result of pluvial flooding. The Environment Agency was one of the first organisations in the world to produce a national surface water flood map to identify areas likely to flood following extreme rainfall events. In France a national surface water flood map has not been produced. This explains the differences between the 
awareness levels. It should be noted that where responders to the survey indicated that the tools "were not relevant to plans" this was generally because they were in landlocked areas or catchments without dams so there no hazard posed by coastal flooding or dam breaks.

\subsubsection{Tools to assess tools to assess risk to people, evacuation routes, accessibility and flood warnings}

Table 6 shows the perceived obstacles for tools to assess risk to people, evacuation routes, accessibility and flood warnings. The perceived use of methods to assess the risk to people in England and Wales is higher than France. This is to be expected as a major research project on this subject commissioned by the Environment Agency was completed in 2006 (Defra/Environment Agency, 2006). The results of this work have fed directly into a number of planning policies; however, despite this there were still almost $63 \%$ of responders who remained unaware of these tools. In France little work on the risk that floods pose to people has been carried out. The general low level of awareness of methods in both countries of risk to people methods may also be a result of the fact that estimating fatalities for theoretical natural disasters can be a very politically sensitive issue (Flores \& Smith, 2010).

Table 6: Perceived obstacles to using tools to assess risk to people, evacuation routes, accessibility and flood warnings

\begin{tabular}{|c|c|c|c|c|c|c|c|c|}
\hline \multirow[b]{2}{*}{ Response } & \multicolumn{2}{|c|}{$\begin{array}{l}\text { Injuries to people } \\
\text { and number of } \\
\text { fatalities }\end{array}$} & \multicolumn{2}{|c|}{$\begin{array}{l}\text { Accessibility of } \\
\text { roads }\end{array}$} & \multicolumn{2}{|c|}{$\begin{array}{l}\text { Optimal } \\
\text { evacuation } \\
\text { routes }\end{array}$} & \multicolumn{2}{|c|}{$\begin{array}{l}\text { Improvements in } \\
\text { dissemination of } \\
\text { flood warning }\end{array}$} \\
\hline & $\begin{array}{l}\text { England } \\
\text { and } \\
\text { Wales }\end{array}$ & France & $\begin{array}{l}\text { England } \\
\text { and } \\
\text { Wales }\end{array}$ & France & $\begin{array}{l}\text { England } \\
\text { and } \\
\text { Wales }\end{array}$ & France & $\begin{array}{l}\text { England } \\
\text { and } \\
\text { Wales }\end{array}$ & France \\
\hline Currently used & $14.3 \%$ & $5.0 \%$ & $31.4 \%$ & $20.0 \%$ & $31.4 \%$ & $16.0 \%$ & $45.7 \%$ & $26.0 \%$ \\
\hline $\begin{array}{l}\text { Not relevant to } \\
\text { plans }\end{array}$ & $5.7 \%$ & $5.0 \%$ & $0.0 \%$ & $0.0 \%$ & $0.0 \%$ & $0.0 \%$ & $5.7 \%$ & $0.0 \%$ \\
\hline Unaware of method & $62.9 \%$ & $68.0 \%$ & $48.6 \%$ & $35.0 \%$ & $57.1 \%$ & $47.0 \%$ & $34.3 \%$ & $53.0 \%$ \\
\hline Cost & $0.0 \%$ & $0.0 \%$ & $0.0 \%$ & $0.0 \%$ & $0.0 \%$ & $0.0 \%$ & $0.0 \%$ & $5.0 \%$ \\
\hline $\begin{array}{l}\text { User friendliness } \\
\text { issues }\end{array}$ & $0.0 \%$ & $5.0 \%$ & $5.7 \%$ & $0.0 \%$ & $0.0 \%$ & $5.0 \%$ & $0.0 \%$ & $0.0 \%$ \\
\hline Availability of data & $14.3 \%$ & $11.0 \%$ & $11.4 \%$ & $40.0 \%$ & $8.6 \%$ & $26.0 \%$ & $5.7 \%$ & $16.0 \%$ \\
\hline Other reasons & $2.9 \%$ & $5.0 \%$ & $2.9 \%$ & $5.0 \%$ & $2.9 \%$ & $5.0 \%$ & $8.6 \%$ & $0.0 \%$ \\
\hline
\end{tabular}

Only a few of the flood risk managers who responded to the survey $(<32 \%)$ were aware of tools to assess the accessibility of roads in flood zones and to assess optimal evacuation routes. For example discussions with one responder indicated that in the case of assessing the accessibility of roads to emergency vehicles often "rule of thumb" methods were used (i.e. emergency services would be told that roads were inaccessible if the depth of water covering a road is more than $200 \mathrm{~mm}$ ) rather than a physically, based method such as those developed by Keller and Mitsch $(1992,1993)$. In France, in general, availability of data is seen as more of an issue than in England and Wales. Again the more joined up nature the organisation of flood risk management in England and Wales means that most of the data required to utilise the various tools is held by one organisation, the Environment Agency, which is far from the case in France. For example the 
Environment Agency has access to the UK's digitised road network data. This data is not readily available to French flood risk managers.

The perceived use of tools to assess evacuation routes and improvements in the dissemination of flood warnings was again higher in England and Wales than in France. Again the more holistic approach to flood risk management by the Environment Agency is reflected in the higher level of use in England and Wales.

\subsubsection{Tools to assess tools to assess risks to critical infrastructure, location of shelters, assessment of NaTechs and the probability of building collapse}

Table 7 details the perceived use of tools relating to risks to critical infrastructure, building collapse, location of shelters and the assessment of other hazards that can be triggered by floods. Following the 2007 floods in England the impacts of flooding on critical infrastructure was raised key issues that need to be improved with respect to the emergency response to floods (Pitt, 2008; ICE, 2009). This is likely to explain the higher awareness of methods in England and Wales relative to France. Issues regarding the availability of data on this subject in both countries are summed up by two flood risk managers who stated that: "It is very hard to acquire but more information on critical infrastructure and their likelihood of flooding would be very beneficial to emergency responders. This data at the moment is very sparse"; and "One of the largest risks is the limited knowledge we have of much of our infrastructure, in terms of location, nature, condition, and impact of failure. The disparate datasets for assets, in particular networks, makes the understanding of total risk difficult to assess."

With regards to the optimisation of shelter locations, assessment of other hazards triggered by floods and the probability of building collapse, these also had some of the lowest levels of awareness regarding the tools. Similar to the assessment of the accessibility of roads many of the responses to the survey suggested that "rule of thumb" measures were being used rather than methods that allowed the concept of "possibilism" to be addressed.

Table 7: Perceived obstacles to using tools to assess risks to critical infrastructure, location of shelters, assessment of NaTechs and the probability of building collapse

\begin{tabular}{|c|c|c|c|c|c|c|c|c|}
\hline \multirow[b]{2}{*}{ Response } & \multicolumn{2}{|c|}{$\begin{array}{l}\text { Potential damage } \\
\text { to critical } \\
\text { infrastructure }\end{array}$} & \multicolumn{2}{|c|}{$\begin{array}{l}\text { Optimising the } \\
\text { locations of } \\
\text { shelters with } \\
\text { respect to } \\
\text { floods }\end{array}$} & \multicolumn{2}{|c|}{$\begin{array}{l}\text { Assessment of } \\
\text { other hazards } \\
\text { triggered by } \\
\text { flooding }\end{array}$} & \multicolumn{2}{|c|}{$\begin{array}{l}\text { Probability of } \\
\text { buildings } \\
\text { collapsing during } \\
\text { floods }\end{array}$} \\
\hline & $\begin{array}{l}\text { Englan } \\
d \text { and } \\
\text { Wales }\end{array}$ & France & $\begin{array}{l}\text { Englan } \\
d \text { and } \\
\text { Wales }\end{array}$ & $\begin{array}{l}\text { Franc } \\
\text { e }\end{array}$ & $\begin{array}{l}\text { Englan } \\
d \text { and } \\
\text { Wales }\end{array}$ & France & $\begin{array}{l}\text { Englan } \\
d \text { and } \\
\text { Wales }\end{array}$ & France \\
\hline Currently used & $29.4 \%$ & $17.0 \%$ & $42.9 \%$ & $24.0 \%$ & $11.4 \%$ & $11.0 \%$ & $0.0 \%$ & $6.0 \%$ \\
\hline Not relevant to plans & $0.0 \%$ & $0.0 \%$ & $0.0 \%$ & $0.0 \%$ & $2.9 \%$ & $0.0 \%$ & $3.0 \%$ & $0.0 \%$ \\
\hline Unaware of method & $35.3 \%$ & $56.0 \%$ & $40.0 \%$ & $59.0 \%$ & $68.6 \%$ & $53.0 \%$ & $72.7 \%$ & $56.0 \%$ \\
\hline Cost & $0.0 \%$ & $0.0 \%$ & $0.0 \%$ & $0.0 \%$ & $0.0 \%$ & $0.0 \%$ & $0.0 \%$ & $0.0 \%$ \\
\hline $\begin{array}{l}\text { User friendliness } \\
\text { issues }\end{array}$ & $0.0 \%$ & $6.0 \%$ & $0.0 \%$ & $0.0 \%$ & $0.0 \%$ & $11.0 \%$ & $0.0 \%$ & $17.0 \%$ \\
\hline Availability of data & $35.4 \%$ & $22.0 \%$ & $11.4 \%$ & $12.0 \%$ & $8.6 \%$ & $26.0 \%$ & $24.2 \%$ & $22.0 \%$ \\
\hline Other reasons & $0.0 \%$ & $0.0 \%$ & $5.7 \%$ & $6.0 \%$ & $8.6 \%$ & $0.0 \%$ & $0.0 \%$ & $0.0 \%$ \\
\hline
\end{tabular}




\section{Discussion}

The survey of flood risk managers in England and Wales and France showed although many flood risk managers used or were aware of methods to assess the flood hazard from various sources there was a low awareness of many of the other tools available. A typical level of awareness of the tools by flood risk managers available in the two countries is summed up by the following response: "There are no dedicated tools or methods employed beyond standard datasets such as the flood extent map." The research showed that generally over half of flood risk managers were not aware of the following types of methods and tools:

- Tools to assess risk to people, evacuation routes, accessibility and flood warnings

- Tools to assess risk to critical infrastructure, location of shelters, NaTechs and the probability of building collapse

User friendliness was not seen by the responders to be an obstacle to the use of tools; however, this may be linked to that fact that there was a high level of unawareness concerning these types of tools meaning that responders were unable to comment knowledgably on these issues. It is interesting to note that cost was not seen as a major constraint for the implementation of the methods. Very few users $(<6 \%)$ indicated that the methods listed in the survey were not relevant to formulation of emergency plans for floods.

The survey of flood risk managers highlighted the need to raise awareness of them. Typical responses provided included: "There may be guidance, methods, or tools in existence that I am unaware of. If so it would be good to give training on these tools to assist in producing emergency plans" and "Educate all staff involved with contributing to emergency plans about what tools are available to us to help us with the plans". The lack of dissemination of tools to assess the impacts on flood or to assess potential damage has already been pointed out in many articles and reports in France (Hubert \& Ledoux, 1999); however, this would also appear to be the case in England and Wales certainly with respect tools that can be used to inform emergency plans.

There is also some times a case of division of responsibility. For example in the case of certain aspects of flood risk management (e.g. estimation of loss of life; evacuation times) it is not always clear who should take the lead (i.e. flood risk managers or emergency planners). This may be because some of the types of tools for improving emergency plans are perceived to fall outside the remit of all the stakeholders. This can mean that tools are not used because there is a "responsibility gap" through which the use of the tools falls.

The floods of 2007 in England and the failure of coastal defences resulting in 47 fatalities in the Vendée region of France show that the two countries remain unprepared for extreme flood events (Pitt, 2008 and MEEDDM, 2011). A recent report on critical infrastructure by the Institution of Civil Engineers (ICE) in the UK provides the following example showing that the concept of planning for the "worst case" or "possibilism" is often not considered. The ICE report illustrates the failure to plan with the example of the Atomic Weapons Establishment site at Burghfield in the UK that was flooded in 2007. All the radiation detection alarms were disabled. If the floodwaters had penetrated only a little further it could have led to the spread of radioactive material, forcing the evacuation of thousands of people and leaving the area near the site uninhabitable for centuries (ICE, 2009).

This failure to plan is also illustrated by the example of Canvey Island in the UK. Canvey Island is located in the Thames Estuary. The mean ground level is below the high tide level. The island is protected from floods by a network of embankments. The island is home to some 37,000 people (Lumbroso \& Di Mauro, 2008). In 1953 the flood defences failed and 58 people were killed as the result of the flooding. Access to Canvey Island is currently only possible by two roads both of which are connected to the same roundabout. Any 
disruption to these routes would hamper evacuation and severely limit access. A number of properties are vulnerable to flooding with $30 \%$ of the housing stock being bungalows and $45 \%$ of flats being located on the ground floor (Kelman, 2002).

Concerns regarding emergency planning have been raised by local communities who state that "major issues" include "the lack of safe havens, lack of a fit for purpose emergency plan and of course the problems associated with evacuation amongst others. The Council has to date not provided evidence that it can confidently provide a robust emergency flood response strategy for Canvey Island, which would be cut off from the mainland for some considerable time during extreme flood conditions" (CGC, 2009a). The risk posed by flooding the possibility of an extreme flood inundating the island has not appear to have been planned for this is despite the fact that urbanisation of Canvey Island, including caravans and mobile homes, has increased the vulnerability of its residents (CGC, 2009b).

As this paper demonstrates there are tools that could assist flood risk managers provide advice to emergency services on the location of safe havens, the accessibility of flooded routes in addition to assessing where the risk to people is highest. However, in England and Wales and France these tools appear to be rarely used by flood risk managers. The main reason would appear to be a lack of knowledge of what tools are available. However, in the UK there may also be an issue with technical capacity. Reports carried out on the skills required for flood risk management in the UK have pointed out that "too few people are being trained to replace the ageing skilled workforce, and too few are acquiring the technical and managerial skills required to get full value from new techniques and technologies." (Environment Agency et al, 2005; ICE, 2005) The down-sizing of public sector technical departments arising from out-sourcing has also left them short of mature professional staff with competencies in the key technical skills to enable these organisations to operate as consistently intelligent clients (ICE, 2005). This lack of technical capacity can in some cases discourage the use of new methods that are not viewed as being "mature".

In the face of low probability events some organisations may suffer from poor intelligence gathering and processing or even a "it can't happen here" mentality (McConnell \& Drennan, 2006). However, as the cases of New Orleans in 2005 and the "Great North Sea floods" that hit Britain and the Netherlands in 1953 demonstrate it can happen here. Emergency planning should be based on a wide variety of scenarios including extreme floods. Even for the worst credible flood there are in some cases simple measures that are not always "obvious" that can be demonstrated using relatively simple tools (e.g. location of safest routes to flooded zones; optimum location of shelters).

\section{Conclusions}

From the research carried out many flood managers are often not aware of the tools that are available to assist them in providing information to emergency plans for floods. Based on the online survey of flood managers in the England and Wales and France, the three main obstacles to tools not being used appear to be:

1. Lack of awareness of the methods that are available

2. Availability of data

3. Lack of communication between flood risk managers and the stakeholders such as emergency services and local authorities responsible for writing the plans

Emergency plans for floods often contain limited information on flood scenarios (e.g. one or two flood extents) and often no information on flood depths and velocities. Plans usually contain actions on what to do 
at certain trigger levels without knowledge of the potential consequences (e.g. in terms of potential risk to life; accessibility of roads etc). The recent coastal floods in France showed although most of the risks were known by some organisations, this knowledge had not been translated into potential consequences in the relevant emergency management plans (MEEDDM, 2010). In formulating emergency plans for floods it would appear that "expert judgement" is often used rather than specific tools. Whilst local knowledge and expert judgement are important in formulating plans many consequences and emergency responses to extreme flood events can only be formulate using tools.

Many responders to the survey mentioned that they used a combination of information rather than specific methods or tools. For example in the survey in England and Wales around half to a third of the responders stated that they were aware of, or used the methods to assess: Accessibility of inundated roads; Optimisation of the location of shelters; Damage to critical infrastructure; Optimal evacuation routes; Effects of improvements in flood warning on the risk to people; and Methods to assess potential injuries and loss of life. However, none of the 44 flood managers who are involved in providing information to assist with the formulation of MAFPs in England and Wales explicitly mentioned any methods or tools that provide such information.

In France the awareness level of the tools and methods available was lower than in England and Wales. The lack of awareness in general may be as a result of a need to improve the dissemination of the tools and the relevant research and the fragmented nature of flood risk management in France. The lack of awareness of tools to assess the consequences of flooding has already been pointed out in many articles and reports in France (Hubert \& Ledoux, 1999).

The split of responsibilities between flood management organisations and authorities responsible for emergency planning means that in some cases neither organisation wishes to be responsible for utilising tools such as loss of life and evacuation models. This is true in both England and Wales and France where the organizations responsible for emergency planning and response fall under different ministries.

Whilst it is acknowledged that some of tools may not yet be "mature" there are many relatively simple tools available that flood risk managers could commence using immediately. The research has indicated that there is to be a requirement for guidance on: what tools are available; what data they require; and how the tools can be implemented to give information that can be used to improve emergency planning for floods. It would also appear that flood risk managers and emergency planners have the potential to improve the effectiveness of emergency plans by working more closely together and start considering "possibilism" more in their plans by using tools that are currently available.

\section{Acknowledgements}

This research was carried out as part of the Flood Incident Management - A FRAMEwork for improvement (FIM FRAME) project carried out as part of the second ERA-Net CRUE funding initiative (http://www.crueeranet.net/). The project is funded by the joint Department for Environment, Food and Rural Affairs (Defra)/Environment Agency Flood And Coastal Erosion Risk Management Research and Development Programme in England and Wales and the Ministère de l'Ecologie, de l'Energie, du Développement durable et de la Mer, en charge des Technologies vertes et des Négociations sur le climat in France. We wish to acknowledge the support of the both the funders, the emergency responders who participated in this research. This work would also not have been possible without the Royal Academy of Engineers (RAEng) who provided a Global Research award to one of the authors. We wish to extend our thanks to the RAEng for their support. 


\section{References}

Aboelata, M.A. and Bowles, D.S. (2005) LIFESim: A model for estimating dam failure life loss, Report to Institute for Water Resources, US Army Corps of Engineers and Australian National Committee on Large Dams Available at: http://uwrl.usu.edu/people/faculty/DSB/lifesim.pdf

Alexander, D. (2005) Towards the development of a standard in emergency planning, Journal of Disaster Prevention and Management Vol.14 No. 2, 2005

Anziani, M.A. (2010) Rapport d'information fait au nom de la mission commune d'information sur les conséquences de la tempête Xynthia, Tome I : Rapport, № 647, Sénat Session Extraordinaire De 20092010

Association of British Insurers (ABI) (2007) Summer floods 2007: Learning the lessons, November 2007

Boin, A., 't Hart, P., Stern, E. and Sundelius, B. (2005), The politics of crisis management. Public leadership under pressure, Cambridge University Press, Cambridge, UK

Bonvicini, S, Spadoni, G. and Cozzani, V. (2009) Development of a framework for the risk assessment of NaTech accidental events, Reliability Engineering and System Safety 94 (2009) 1442-1450

Canvey Island Greenbelt Campaign (CGC) (2009a) Submission on the PPS25: Development and flood risk sequential test and exception test update, September 2009 Available at:

http://www.canveygb.co.uk/data/SeqandExcept.pdf

Canvey Island Greenbelt Campaign (CGC) (2009b) Presentation to Castle Point Borough Council's special policy and development group August 2009 Canvey green belt campaign Available at: http://www.canveygb.co.uk/data/CGBC Presentation.pdf

Clarke, L. (1999) Mission improbable: Using fantasy documents to tame disaster, The University of Chicago Press ISBN 0-226-10941-0

Clarke, L. (2006), Worst cases. Terror and catastrophe in the popular imagination, The University of Chicago Press, Chicago

Clausen, L. and Clark, P.B. (1990) The development of criteria for predicting dambreak flood damages using modelling of historical dam failures in the international conference on River Flood Hydraulics, edited by W. R. White, 17-20 September, 1990. John Wiley \& Sons Ltd, Hydraulics Research Limited, 1990. pp. 369-380

Cœur, D. (2002) Aux origines du concept modern de risque naturel en France, Le cas des inondations fluviales (XVIle - XIXe s.) in Favier R. and Granet-Abisset A.M. Histoire et mémoire des risques naturels CNRS MSH Grenoble p.117-137

Cumbria Local Resilience Forum (LRF) (2010) Use of Multi Agency Flood Plan in the November 2009

Cumbria Floods, Cumbria LRF Flood Planning Sub-Group, 3 February 2010

Dartmouth Flood Observatory (2010) Global active archive of large flood events

Department for the Environment Food and Rural Affairs (Defra)/Environment Agency (2006) Flood risks to people, Phase 2, FD2321/TR2 Guidance Document, March 2006

Department for the Environment Food and Rural Affairs (Defra)/Environment Agency (2008) Who benefits from flood management policies? R\&D Final Report FD2606 
Di Mauro, M. and Lumbroso, D.M. (2008) Hydrodynamic and loss of life modelling for the 1953 Canvey Island flood in Proceedings of the International Conference FloodRisk, Oxford, September 2008

Direction De La Defense Et De La Securitie Civiles (2004) Plan Communal de Sauvegarde - Guide Practique D'Elaboration

Drabek, T.E. and Hoetmer, G.J. (1991) Emergency management: Principles and practice for local government, International City Management Association, Washington DC, USA

Dupray, S., Tourment, R., Pohl, R., Schelfhout, H., Williamson, T., Gamst, K., and Sharp, M. (2010) International levee handbook - Scoping report Available at:

http://www.ciria.org/service/Home/AM/ContentManagerNet/ContentDisplay.aspx?Section=Home\&ContentID $=17434$

EM-DAT-CRED (2011) The international disaster database on the epidemiology of disasters web site wwww.emdat.be Accessed: 21 January 2011

Enjolras, G., Erdlenbruch, K., Grelot, F., Kast, R., Thoyer, S. (2008) Flood management at the basin level in France: Sustainability of local risk-sharing policies World Water Congress 2008 Available at http://www.worldwatercongress2008.org/resource/authors/abs612 article.pdf

Environment Agency/DEFRA/Institution of Civil Engineers (ICE) (2005) Action on engineering skills shortages in flood risk management

Environment Agency (2009a) Flooding in England: A national assessment of flood risk

Environment Agency (2009b) Flooding in Wales: A national assessment of flood risk

Environment Agency/DEFRA/Civil Contingencies Secretariat (2009) Checklist for Multi-Agency Flood Plans (MAFP) 15 December 2009

Environment Agency (2010) The costs of the summer 2007 floods in England Project, ISBN: 978-1-84911146-1, published by the Environment Agency, Bristol, UK

European Commission (EC) (2007) Directive 2007/60/EC of the European Parliament and of the Council of 23 October 2007 on the assessment and management of flood risks

Fischer III, H.W. (1996) What emergency management officials should know to enhance mitigation and effective disaster response, Journal of contingencies and crisis management Volume 4, Number 4, December 1996

Flores, A.Q. and Smith, A. (2010) Surviving disasters, Paper published by the Wilf Family Department of Politics, New York University, New York, USA

Garnier E. and Surville F. (2010) La tempête Xynthia face à l'histoire. Submersions et tsunamis sur les littoraux français du Moyen Age à nos jours. Le croît vif- éditions charentaises 176 p. ISBN : 978-2-36199009-1

Gilbert, S. (1986) The Thames Barrier, Thomas Telford Ltd, 30 June 1986 pp216, ISBN 0-727-70249-1

Graham, W.J. (1999) A procedure for estimating loss of life caused by dam failure, DSO-99-06

Hubert, G. and Ledoux, B. (1999) Le coût du risque: L'evaluation des impacts socio- economiques des inondations, Presses de l'Ecole Nationale des Ponts et Chaussées, Paris, 232, 1999 
Institution of Civil Engineers (2005) Engineering skills for flood risk management: A report by the ICE task team on skills shortages

Institution of Civil Engineers (2009) The state of the nation: Defending critical infrastructure published by the Institution of Civil Engineers, July 2009

Jackson, J.H. (2010) Paris under water: How the city of light survived the Great Flood of 1910, New York, Palgrave Macmillan, 2010

Johnstone, W.M., Sakamoto, D., Assaf, H. and Bourban, S. (2005) Architecture, modelling framework and validation of BC Hydro's virtual reality life safety model in ISSH, Stochastic Hydraulics. Nijmegen

Jonkman, S.N. (2007) Loss of life estimation in flood risk assessment, PhD thesis, Delft University of Technology, the Netherlands

Keller, R.J and Mitsch, B. (1992) Stability of cars and children in flooded streets, International symposium on urban storm water Sydney 4-7 February 1992

Keller, R.J and Mitsch, B. (1993) Safety aspects of design roads as floodways, Research report No. 69, Urban Water Research Association of Australia, International symposium on urban storm water Sydney 4-7 February 1992

Kelman, I. (2002) Physical flood vulnerability of residential properties in coastal, eastern England,

Dissertation submitted for the degree of Doctor of Philosophy, September 2002, University of Cambridge, UK

Kolen, B., Slomp, R., van Balen, W., Terpstra, T, Bottema, M., and Nieuwenhuis, S. (2010) Learning from

French experiences with storm Xynthia - Damages after a flood ISBN 978-90-77051-77-1

Lagadec, P. (2002) Crisis management in France: Trends, shifts, perspectives, Journal of contingencies and crisis management, Volume 10, Number 4, December 2002

Lagadec P. and Guilhou X. (2002) La fin du risque zéro, Eyrolles société - Les échos éditions, p 316, Paris, France

Le Monde (2010) En France, la gestion des digues est un véritable casse-tête, Le Monde newspaper, 4 March 2010

Lorenzen, R.T.; Black, R.D.; Nieber, J.L. (1975) Design aspects of buildings for flood plain locations, ASAE Paper, 68th Annual Meeting, Davis, June 22-25 1975, ASAE St. Joseph, Michigan 20p Paper: 75-4037

Lumbroso, D.M. and Di Mauro, M. (2008) Recent developments in loss of life and evacuation modelling for flood event management in the UK. In Flood Recovery, Innovation and Response, ed. D. B. Proverbs, C.A. and Penning-Roswell E., 263-272. WITpress

Lumbroso, D.M., Stone, K., Vinet, F. and Gaume, E. (2010) CRUE Research Report No 1: Flood Incident Management - A FRAMEwork for improvement - FIM FRAME - The effectiveness and robustness of emergency plans for floods

Lumbroso, D.M., Stone, K. and Vinet, F. (2011) An assessment of flood emergency plans in England and Wales, France and the Netherlands, Natural Hazards, Volume 58, Number 1, July 2011

Marsh, T.J. and Hannaford, J. (2007) The summer 2007 floods in England and Wales - a hydrological appraisal Centre for Ecology \& Hydrology. 32pp. ISBN: 978-0-9557672-4-1

McConnell, A and Drennan, L (2006) Mission impossible? Planning and preparing for a crisis, Journal of contingencies and crisis management, Volume 14, Number 2, June 2006 
Ministère De L'Ecologie Et Du Développement Durable Directions Régionales De L'Environnement (MEEDDM) (2004) SCHAPI - Service Central d'Hydrométéorologie et d'Appui à la Prévision des Inondations Ministère De L'Ecologie Et Du Développement Durable Directions Régionales De L'Environnement (MEEDDM) (2010) Tempête Xynthia - Retour d'expérience, évaluation et propositions d'action. Rapport du gouvernement français, Mai 2010, 2 Tomes.

Ministère De L'Ecologie Et Du Développement Durable Directions Régionales De L'Environnement (MEEDDM) (2011) Plan submersions rapides: Submersions marines, crues soudaines et ruptures de digues

National Audit Office (NAO) (2007) Environment Agency: Building and maintaining river and coastal flood defences in England, ISBN: 9780102945522 , published by the London: The Stationery Office, UK

Penning-Rowsell, E., Johnson, C., and Tunstall, S. (2006) 'Signals' from pre-crisis discourse: Lessons from UK flooding for global environmental policy change? Global Environmental Change 16 (2006) pp323-339

Perry, R. W. and Lindell, M.K. (2003) Preparedness for emergency response: Guidelines for the emergency planning process, Disaters, Volume 27, Number 4, pp 336-350

Pitt, M. (2008) Learning lessons from the 2007 floods Available at http://archive.cabinetoffice.gov.uk/pittreview/thepittreview/final_report.html

Pottier, N, Penning-Rowsell, E., Tunstall, S. and Hubert, G. (2005) Land use and flood protection: contrasting approaches and outcomes in France and in England and Wales Applied Geography 25 (2005) 1-27

Rodda, H.J. (2010) Extreme precipitation and flooding in NW England and SW Scotland: November 2009, Event Science Report 01, Benfield Hazard Research Centre

Sagan, S. (1993) The limits of safety: organizations, accidents, and nuclear weapons. Princeton, N.J: Princeton University Press, USA

Smith, D.I. (1994) Flood damage estimation - A review of urban stage-damage curves and loss functions, Water SA, Vol. 20, No. 3 July 1994. p. 231-238

Tapsell, S.. and Ball, D.J. (2007) Flood event management, Chapter 20, in Future flooding and coastal erosion risk, ed. C. Thorne, E.P. Evans, E.C. Penning-Rowsell, Thomas Telford Services Ltd

ten Brinke, W.B.M., Saeijs, G.E.M., Helsoot, I. and van Alphen, J. (2008) Safety chain approach in flood risk management, Proceedings of the Institution of Civil Engineers, Municipal engineer, 2008, vol. 161, no2, pp. 93-102

ten Brinke, W.B.M., Kolen, B, Dollee, A., van Waveren, H. and Wouters, K. (2010) Contingency planning for large floods in the Netherlands, Journal of Contingencies and Crisis Management, Volume 18, Number 1 , March 2010

van Alphen, J. Martini, F., Loat, R, Slomp, R. and Passchier, R. (2009) Flood risk mapping in Europe, experiences and best practices, Journal of Flood Risk Management 2 (2009) 285-292

Versini, P., Gaume, E. and Andrieu, H. (2010) Application of a distributed hydrological model to the design of a road inundation warning system for flash flood prone areas, Natural Hazards Earth System Science, 10, pp 805-817, 2010 